Books Natalia Pamuła-Cieślak omówiła platformę udostępniającą i wyszukującą książki wydawane w modelu otwartego dostępu, skupiając uwagę na modelu funkcjonowania serwisu, upowszechnianiu wiedzy o otwartych książkach i wydawcach oraz porównaniu działania platformy DOABooks z jej podobnymi. Odczyt Alternatywne wydania przewodników po Krakowie: e-przewodniki Marzeny Błach miał za zadanie próbę przedstawienia metodologii badań nad e-przewodnikami na przykładzie publikacji dotyczących Krakowa. W prelekcji Nie tylko biblioteki. Cyfrowe materiały informacyjne na stronach polskich parków narodowych Michał Rogoż omówił ofertę Polskich Parków Narodowych w zakresie cyfrowych zasobów informacyjnych związaną głównie z badaniami naukowymi, edukacją ekologiczną oraz turystyką stanowiącą zazwyczaj uzupełnienie istniejących zasobów drukowanych.

Reasumując, na konferencji w ciągu dwóch dni, wygłoszono 22 referaty w pięciu sesjach tematycznych mających związek z funkcjonalnością i dostępnością mediów cyfrowych, integracją zasobów cyfrowych w bibliotekach, udostępnianiem dokumentów elektronicznych, użytecznością i recepcją książki elektronicznej a rynkiem dokumentów elektronicznych.

Sponsorami konferencji były firmy: Elibron, Międzynarodowe Centrum Budownictwa, Ebsco oraz Ibuk Libra.

W konferencji udział wzięło 67 uczestników, przedstawicieli wielu ośrodków, nie tylko akademickich, ale także bibliotek pedagogicznych, publicznych oraz szkolnych. Organizatorzy planują wydać publikację pokonferencyjną, a za dwa lata zorganizować piątą Konferencję Naukową z cyklu „Biblioteka w przestrzeni edukacyjnej”.

Agnieszka Folga

Joanna Kołakowska

Biblioteka Główna Uniwersytetu Pedagogicznego w Krakowie

\title{
III Konferencja Naukowa Konsorcjum BazTech Bibliograficzne bazy danych: perspektywy i problemy rozwoju
}

Kraków, 26-27 czerwca 2017

Bibliografio! Ty nad poziomy wylatuj!

W dniach 26 i 27 czerwca 2017 w Krakowie odbyła się III Konferencja Naukowa Konsorcjum BazTech zatytułowana Bibliograficzne bazy danych: perspektywy i problemy rozwoju. W tym roku zorganizowały ją Biblioteka Politechniki Krakowskiej i Biblioteka Główna Uniwersytetu Technologiczno-Przyrodniczego w Bydgoszczy. Honorowy patronat objęli JM Rektor Politechniki Krakowskiej prof. dr hab. inż. Jan Kazior oraz JM Rektor Uniwersytetu Technologiczno-Przyrodniczego prof. dr hab. inż. Tomasz Topoliński. Poprzednie konferencje Konsorcjum BazTech miały miejsce w 2013 r. (Bibliograficzne bazy danych i ich rola w rozwoju nauki, Poznań) i 2009 r. (Bibliograficzne bazy danych: kierunki rozwoju i możliwości współpracy, Bydgoszcz).

Zakres omawianych problemów szczegółowo został określony w zaproszeniu i obejmował:

- tworzenie dziedzinowych baz danych rejestrujących artykuły z czasopism, 
- znaczenie baz bibliograficznych dla upowszechniania nauki,

- wsparcie procesu oceny czasopism naukowych przez bazy bibliograficzne,

- rola i miejsce baz danych w rozwoju otwartej nauki, w tym otwartego dostępu do treści naukowych,

- programy do edycji, udostępniania i agregowania baz,

- analizy bibliometryczne i webometryczne,

- zasoby bibliograficznych baz danych a inne serwisy, np. repozytoria (w tym też repozytoria surowych danych), wyszukiwarki naukowe, bazy cytowań, platformy czasopism,

- współpraca z wydawcami i redakcjami czasopism,

- najlepsze praktyki i standardy wydawnicze,

- sposoby skutecznego rozpowszechniania informacji o bazach, głównie w środowisku naukowców, studentów oraz wydawców i redakcji czasopism.

Organizatorzy pogrupowali zgłoszone referaty w pięć sesji tematycznych. Pierwsza - wprowadzająca - składała się z trzech wystąpień. Jan Kozłowski, radca w Ministerstwie Nauki i Szkolnictwa Wyższego, zatytułował swoją wypowiedź Bibliografia - gatunek z przyszłościa czy gatunek zagrożony? Na panoramicznym tle historii bibliografii, jako gatunku piśmienniczego oraz zmian, które obecnie dokonują się w jej otoczeniu społecznym, naukowym, gospodarczym, politycznym, technologicznym, uwzględniając koncepcję Kevina Kelly’ego strategii dla świata połączonego z siecią, prelegent zadał kilka ważnych pytań o przyszłość bibliografii, pozostawiając otwartą kwestię odpowiedzi na nie. Moją uwagę zwróciły zwłaszcza trzy następujące pytania: (1) Jeśli bibliografia jest zbiorem opisów publikacji dokonanych za pomocą takich standardowych charakterystyk, jak m.in. autor, tytuł, słowa kluczowe, streszczenie, cytowania, czyli innym słowy "mapą", jaka może być jej rola, gdy mamy dziś bezpośredni dostęp do „terytorium”, czyli samych publikacji (otwarty dostęp)? (2) Czy bibliograf nie powinien posunąć się o ogniwo (lub ogniwa) dalej w „łańcuchu wartości” tworzenia wiedzy i przeobrazić się w „meta-analityka”, „eksploratora tekstu”, „syntetyka”? (3) Czy bibliografie nie chwytają tylko pewnych elementów publikacji, przeoczając przy tym inne ważne składniki (styl, dane, podejścia itd.)? W zacytowanych pytaniach są zawarte supozycje odpowiedzi - nie ze wszystkimi mogę się zgodzić. Metafora bibliografii jako mapy przemawia do wyobraźni. Dziś już pewnie niewiele osób korzysta z papierowych map, planów miast czy przewodników. Zastąpiły je nawigacje, aplikacje w telefonach usprawniające poruszanie się na przykład po nieznanym mieście, przewodniki cyfrowe, audio (ciągle powszechne w muzeach i galeriach) itp. Ale czy mimo wszelkich różnic sprzętowo-technologicznych nadal nie służą realizacji tego samego ważnego zadania, jakim jest identyfikowanie i informowanie poprzez przeprowadzenie mnie z punktu A do punktu B, czasami z uwzględnieniem jakiś dodatkowych informacji? Czy wiele jest osób, które podjęłyby ryzyko przejechania samochodem „tylko” z Suwałk do Faro bez wsparcia się jakąś „mapą”, choć terytorium jest i jest otwarte? Oczywiście, bez udziału bibliografii też się da coś znaleźć, ale czy istotnie zawsze chodzi nam o „coś” zamiast „to, co optymalne" (cokolwiek by to miało znaczyć w konkretnym przypadku)? Poza tym nie możemy zapominać, że każda bibliografia pełni jeszcze jedną istotną rolę - jest depozytariuszem obrazu dorobku jakiejś dyscypliny, narodu, państwa, regionu itd. Podlega zasadom archiwizacji i zachowania, które nie dotyczą rejestrowanych obiektów. Całkowicie się zgadzam, że należy zintegrować rejestrację bibliograficzną z rejestracją samych dokumentów, obiektów, ale nie rezygnować z tej pierwszej, bo ona wnosi porządek - wartość naddaną - do repozytorium, archiwum tekstów. Zresztą, autor referatu sam sugeruje, że możliwe i potrzebne byłoby rozszerzenie owego „łańcucha wartości”. Wnikliwego rozważenia, wykraczającego poza ograniczenia tej wypowiedzi, wymagają pytania drugie i trzecie. Bezpośrednia odpowiedź, której udzieliłabym na nie, brzmi tak. Ale diabeł tkwi w szczegółach, zwłaszcza, że jak słusznie zauważył prelegent, przeobrażenia badań naukowych już zaczynają chwiać tradycyjnie rozumianą publikacją jako podstawową jednostką opisu bibliograficznego.

W sesji wprowadzającej były jeszcze dwa inne referaty: Jadwigi Sadowskiej Bibliografia dziedzinowa dzisiaj - jej rola i perspektywy oraz Henryka Hollendra Bibliografia dla nauki a nauka na krawędzi. 
Co robimy? Pierwszy z wymienionych referatów był rekapitulacją wiedzy na temat bibliografii dziedzin i poglądów J. Sadowskiej na ich przyszłość. W drugim H. Hollender zwrócił uwagę na, z jednej strony zjawisko stygmatyzowania pewnych typów wypowiedzi naukowych (np. recenzje), z drugiej zaś „zrytualizowane naśladownictwo”, prowadzące do „stopniowego psucia jakości tekstów” i poziomu czasopism („Czasopisma drapieżne i tandetne jako przepustka do świata wpływu [impact]). Wprowadził do wywodu pojęcie nauki aparadygmatycznej (post-normalnej) jako zacierającej granice między wiedzą naukową a jej zastosowaniami i wdrożeniami, „w obrębie której funkcjonują nierozwiązywalne sprzeczności pomiędzy «niepewnymi faktami, nieuzgodnionymi wartościami, wysokim ryzykiem i pilną potrzebą decyzji»”. Celnie zwrócił uwagę na uwikłania nauki „normalnej” stymulowane przez biurokrację, której nauka podlega, m.in. takie jak „błędy w wykorzystywaniu statystyki; nadmierna ufność, pokładana w data mining; bałamutne zachęty (publish or perish); przeciwskuteczne wskaźniki i pomiary”. W referacie znalazły też miejsce refleksje dotyczące rozpoznawania „jakości i doniosłości" tekstu (z udziałem bibliografa i algorytmów sztucznej inteligencji) oraz potencjalnego udziału bibliografii w dokumentowaniu tych zjawisk i ich efektów. Szeroko pojmowana racjonalność nauki, jak i jej udział w praktycznym opanowaniu i przekształcaniu świata moim zdaniem tworzą większą rewolucję niż jakakolwiek zmiana paradygmatu. Jeśli od nauki oczekuje się użyteczności, praktyczności, zastosowalności, to prawdziwość wiedzy naukowej przestaje być konieczna (żeby spełnić warunek użyteczności). A to już na skróty prowadzi do tego, nad czym ubolewał H. Hollender. Osobiście relację nauka normalna $\div$ nauka post-normalna widzę jako komplementarną, a nie jako człony alternatywy. Produkty jednej i drugiej powinny być w sferze zainteresowań bibliografów, co nie oznacza, automatyzmu rejestracji bibliograficznej i jednych, i drugich.

Kolejną sesję wypełnił przegląd zasobów, użytkowników i użytkowania krajowych baz bibliograficznych: AGRO (Zofia Kasprzak, Mariusz Polarczyk, Krzysztof Gmerek Przyrodnicze i rolnicze zasoby nauki udostępniane cyfrowo w bazie AGRO), BazHum (Klaudia Grabowska BazHum w dziataniu. Badania użytkowników bazy czasopism), BazEkon (Urszula Cieraszewska BazEkon - bogactwo wiedzy i możliwości), BazTech (Katarzyna Bikowska Marketing społecznościowy czy społeczności? Promocja bibliograficznej bazy danych BazTech), BEP (Inga B. Kuźma, Małgorzata Wilbik, Anna Deredas, Alicja Piotrowska, Bibliografia Etnografii Polskiej (BEP) jako narzędzie pomocne w informacji naukowej i dydaktyce), PEDAGOG (Dorota Wierzbicka-Próchnika, Danuta Szewczyk Baza PEDAGOG - czy dziedzinowe bazy danych nadal sa potrzebne użytkownikom informacji naukowej?), PBLekarska (Dorota Ubysz, Jacek Głębocki, Polska Bibliografia Lekarska - perspektywy rozwoju), PBLiteracka (Karolina Jaworska, Beata Koper, Tomasz Umerle, Piotr Wyciślik, Polska Bibliografia Literacka - nowe wyzwania).

Pierwszy dzień obrad zamknęła sesja zatytułowana „Bibliograficzne bazy danych - perspektywy” oraz dyskusja panelowa. W sesji tematycznej wystąpili Emanuel Kulczycki (Rola baz danych w ocenie czasopism naukowych w Polsce - aktualne cele i wyzwania polityki naukowej) oraz Marek Niezgódka (Perspektywy rozwoju modeli otwartej nauki w Polsce). Kulczycki w swoim referacie zwrócił uwagę m.in. na ważny aspekt udziału baz danych (bibliografii zawartości) nie tylko w ewaluacji periodyków, ale również w realnym kształtowaniu polityki naukowej w Polsce. Sformułował tezę, że żadne polskie bazy nie powinny być w żaden sposób brane pod uwagę w instytucjonalnej ewaluacji nauki w Polsce, natomiast powinny być finansowane oraz wspierane jako element systemu informacji i komunikacji naukowej. Końcowe pytania referatu, a wśród nich: Komu są potrzebne bibliograficzno-abstraktowe bazy danych w czasach Web of Science, Scopusa, Google Scholar i Microsoft Academic? Kto używa baz dziedzinowych? Skoro klasyfikacje dziedzin i dyscyplin tracą znaczenie, to po co robić bazy dziedzinowe? Jak finansowanie baz przekłada się na realizacje celów polityki naukowej? W jaki sposób bazy mogą wspierać inną sferę naukowej praktyki niż ewaluacja czasopism na potrzeby oceny instytucjonalnej? są niewątpliwie ważne i koniecznie należy im się namysł, choć nie można też nie zauważyć w nich pewnej dozy politykierstwa. Jak mantrę powtórzę, że reagowanie na aktualne (najlepiej rozumiane) zapotrzebowanie polityczne nie może być naczelną regułą przestrzeganą 
w nauce, a także w bibliotekach. Wysoko wznosimy sztandar racjonalizacji wydatków, na przykład wstrzymując finansowanie wielkich i ważnych przedsięwzięć bibliograficznych, jak Bibliografia Historii Polskiej, a hojną ręką finansujemy kolejne tworzone bez składu i ładu biblioteki cyfrowe i inne paranaukowe „projekty”.

Punktem wyjścia wystąpienia Marka Niezgódki było stwierdzenie, że nauka (nie tylko) w Polsce jest w stanie kryzysu powodowanego $\mathrm{m}$. in. jej systemową zamkniętością. Otwartość nadal jest w większym rozmiarze ideą niż praktyką. Zdaniem M. Niezgódki najważniejsze dylematy i wyzwania stojące przed otwartą nauką w Polsce to przede wszystkim: brak decyzji (niesprzecznych z działaniami oddolnymi) o krajowej infrastrukturze danych i publikacji, brak spójności decyzyjnej skutkującej wielokrotnym finansowaniem zbliżonych działań, brak świadomości znaczenia trwałości e-infrastruktur. W referacie zwrócono również uwagę na znaczenie spójnej koncepcji nowego krajowego modelu publikowania naukowego i dokumentowania wyników naukowych (otwarte platformy, zróżnicowane i otwarte modele recenzowania, uznanie integralnej przynależności dokumentacji badawczej do procesu naukowego i co za tym idzie konieczność jej publikacji itp.). Według M. Niezgódki w Polsce obserwujemy obecnie pogłębiające się cofnięcie w stosunku do międzynarodowych standardów ewaluacji instytucjonalnej i oceny indywidualnej aktywności naukowej. Potrzebujemy „zdrowych relacji krajowej e-infrastruktury informacji naukowej (publikacje, dane badawcze, dokumentacja itp.) i dostępu do zasobów zagranicznych w modelu gwarantującym trwałość".

Pierwszy dzień prac konferencji zamknęła dyskusja panelowa "Gramy do jednej bramki” z udziałem Marka Niezgódki (ICM UW), Emanuela Kulczyckiego (UAM), Jana Kozłowskiego (MNiSZW), Małgorzaty Paszkowskiej (OPI PIB), Jolanty Przyłuskiej (Instytut Medycyny Pracy) i Danuty Szyszki (redakcja czasopisma „Mining Science”), moderowana przez Dorotę Buzdygan i Lidię Derfert-Wolf. Osiami problemowymi dyskusji, zaproponowanymi przez organizatorów, były następujące zagadnienia: polityka naukowa państwa, parametryzacja jednostek naukowych i ocena czasopism naukowych, współdzielenie krajowych zasobów informacyjnych, kierunki rozwoju baz bibliograficznych.

Drugiego dnia referaty dotyczyły roli baz w komunikacji naukowej oraz praktyk i standardów wydawniczych czasopism naukowych w Polsce. W pierwszej grupie znalazły się wypowiedzi Anety Drabek Czasopisma Open Access w polskich bazach danych, Edyty Strzelczyk Otwarte dane badawcze - kolejny krok do otwierania nauki, Małgorzaty Rychlik Upowszechnianie dorobku naukowego w repozytoriach $i$ bazach danych - działania komplementarne czy konkurencyjne?, Marzeny Błaszczyńskiej, Michała Kozaka, Cezarego Mazurka, Marcina Szymczaka i Marcina Werli System SINUS - otwarte narzędzie do budowy bibliograficznych baz danych. Z badań A. Drabek wynika m.in., iż bazy danych stanowią trzeci co do popularności kanał dostępu do informacji i tekstów publikacji naukowych. Jest to również odpowiedź na pytanie E. Kulczyckiego „Kto używa baz dziedzinowych?”. Badając dostępność do pełnych tekstów, referentka zauważyła, że informacja o możliwościach wykorzystania pełnych tekstów jest słabo widoczna, brak jest takiej informacji (lub jest niedostateczna) na stronach czasopism ( 266 z 885), w artykułach brak z kolei danych o licencji (uwaga ta nie dotyczy bazy BazHum). Referaty Edyty Strzelczyk i Małgorzaty Rychlik zawierały wiele cennych, niekiedy szczegółowych informacji, których nie sposób streścić w sprawozdaniu. Zachęcam do ich lektury (jak i wszystkich pozostałych tekstów), gdy zostaną opublikowane $e^{4}$.

W grupie referatów omawiających praktyki i standardy wydawnicze czasopism naukowych w Polsce znalazły się wystąpienia: Małgorzaty Kowalskiej Platformy czasopism naukowych a bibliograficzne bazy danych: obszary przenikania, narzędzia, ustugi, Danuty Szyszki Budowanie i wdrażanie strategii rozwoju czasopisma naukowego „Mining Science”, Ewy Rozkosz Wykorzystanie diagramów COPE w zasadach etyki publikacyjnej czasopisma naukowego, Natalii Pamuły-Cieślak Polskie czasopisma otwarte w Directory of Open Access Journal - aplikowanie, indeksowanie i dobre praktyki. Powinny

${ }^{4}$ Organizatorzy zapowiadają opublikowanie pełnych tekstów wystąpień online w serii „Materiały Konferencyjne EBIB" oraz w repozytorium e-LIS. 
się z nimi zapoznać zwłaszcza osoby zaangażowane w wydawanie czasopism naukowych, chcące rozwijać ich jakość, doskonałość, otwartość. Warto zaznaczyć, że organizatorzy konferencji umożliwili udział w obradach licznemu gronu wydawców i redaktorów czasopism.

$\mathrm{Z}$ mojego punktu widzenia konferencja „Bibliograficzne bazy danych: perspektywy i problemy rozwoju" była niezwykle wartościowa i udana. Na sukces złożyło się kilka czynników, a wśród nich: staranne i szczegółowe opracowanie koncepcji konferencji i jej realizacja przez zespoły z bibliotek Politechniki Krakowskiej i Uniwersytetu Technologiczno-Przyrodniczego w Bydgoszczy, którym przewodzili Dorota Buzdygan, Marek Górski i Lidia Derfert-Wolf; znakomite grono prelegentów, którzy podjęli trud podzielenia się z licznie zebranymi uczestnikami (ponad 160 osób!) swoją wiedzą, doświadczeniem, poglądami; atmosfera sprzyjająca otwartej wymianie myśli i poglądów. Tylko poprzez dialog i wzajemne wsłuchiwanie się w swoje racje możemy zbliżyć się do prawdy, w tym również i tej dotyczącej obecnego i przyszłego statusu bibliografii, także bibliografii dziedzinowych. Na zakończenie dodam, że w moim odczuciu zaobserwowane różnice poglądów częściowo biorą się z pewnej nieprecyzyjności wypowiedzi. Czasami jest to efekt „nieznośnej lekkości” wypowiadania się, a czasami braku szerszego spojrzenia na poruszane zagadnienia. Tak czy owak, szkoda, że na następną konferencję z tego cyklu trzeba będzie czekać cztery lata.

Jadwiga Woźniak-Kasperek

Katedra Bibliografii i Dokumentacji

Wydziat Dziennikarstwa, Informacji i Bibliologii

Uniwersytet Warszawski

Nadestano: 24 sierpnia 2017 